\title{
Research on the Characteristics of Tourism Consumption Based on Network Data: A Urban-rural Perspective
}

\author{
Qihong Tan \\ Leisure Management School, Xi'an Eurasia University, Xi'an, \\ Shaanxi 710065, China \\ tanqihong@eurasia.edu
}

\begin{abstract}
With the rapid development of online travel industry in our country, more and more tourists begin to get travel information, booking travel products through the network. The author first analyzes the characteristics of tourism consumption demand, and finds out the key factors affecting tourism consumption based on urban and rural areas. The result shows that the income level of consumers, the price of tourism products, the quality of tourism products are the key factors affecting the urban residents, while rural residents pay more attention to the tourist will and the price of tourism products. Consumption awareness is the most important factor that will affect tourism consumption of rural residents, the higher education rate among rural residents increase 1\% will lead rural residents per capita tourism consumption increase 32.16 RMB. On this basis, we put forward relevant policy suggestions.
\end{abstract}

Keywords: Network data; tourism consumption; income level; statistical analysis

\section{Introduction}

After the reform and opening up, China economy at an annual rate of more than $8 \%$ sustained and rapid development, get rid of the poverty situation most people even have adequate food and clothing cannot solve, improve the people's living standards, enhance the strength of the national economy. At the same time, abuse of growth imbalance in the structure of China's economy is gradually revealed, performance in the GDP growth mode on heavy investment, light consumption; heavy external demand, domestic demand for light. The rapid development of China's economy due to the huge investment in fixed assets, emphasis on equipment, infrastructure investment, and consumption in GDP growth in the contribution accounted for only $30 \%-40 \%$. From the specific measures to implement the new development view, promote the residents in the final consumer demand to expand domestic demand is quick, sustainable economic growth means, because it not only can directly lead to economic growth, but also can lead to intermediate consumption of all walks of life [1]. Bring greater economic growth, tourism consumption and rural consumption, housing consumption, automobile consumption, service consumption tied together to become the current needs of our country to develop the five major types of consumption. In view of tourism consumption in the expansion of the important role of final consumption demand, the government sets the tourism industry in the national economy industry strategic positioning, clear the tourism industry with low resource consumption, driving coefficient, more employment opportunities, good comprehensive benefits, in the current our country is in the industrialization, development period of urbanization and tourism should be give full play to the tourism industry in maintaining growth, the positive role of expanding domestic demand, adjusting the structure, adhere to the domestic tourism as the focus, the positive development of inbound tourism, orderly development of the outbound tourism. 
With the important role of domestic tourism to the economic growth is becoming more and more obvious, the majority of scholars of domestic tourism research interest is becoming strong, a year of research center of travel of the Chinese Academy of social sciences will publish special reports of China's domestic tourism present situation analysis and trend prediction. Report in addition to the current number of travel, travel rate, domestic tourist expenditure, per capita spending. Image data analysis, also the annual development context and development characteristics make analysis, and forecast in the report at the end of this paper, the development of domestic tourism. Continuity of the report is good, practical strong, due to the report year, so in addition to reflect the effects of long-term factor of domestic tourism, but also to capture the role of short-term factors, such as in the analysis of factors of 2009, China's domestic tourism development, in addition to mention disposable income factors, tourism industry progress and clusters of long-term factors, also referred to the impact of the financial crisis, the coupons measures the role of short-term factors. Although the research on domestic tourism consumption of the majority of scholars have made a lot of achievements, but these research results both from the quantity or quality point of view there are still some unanswered question. China's domestic tourism has two structures in urban and rural areas significantly, from the common sense point of view; the key should be different effects of the two factors. However, most of the studies all adopt the national data and the mixture of the two as one, apparently this study does not allow us to understand the different between urban and rural areas of the domestic tourism consumption mechanism, lacking the research results is not suitable for the formulation of relevant recommendations are raised and policy[2]. Therefore, the search for urban and rural domestic tourism consumption market in the different development of key factors can be targeted to improve the consumption ability of urban and rural residents' domestic tourism. Secondly, in the end consumer market, China's domestic tourism market belongs to the buyer or the seller market, in other words, is stimulating consumer demand for the domestic tourism market, tourism or manufacturers supply stimulating effect on the domestic tourism market, some studies show that consumers' disposable income, leisure time, consumption, and other factors affecting the supply the tourism industry of domestic tourism consumption, but only on the above factors be arranged analysis, and involves the study of the relationship between various factors, no comparison of the domestic tourism market forces of supply and demand, did not answer the rapid development of the domestic tourism market in our country is based on strong consumer demand or rich the tourism industry supply contribution. In addition, the domestic tourism consumption is the daily consumption of component part of urban and rural residents, thus affecting other consumer behavior of macroeconomic policy will influence domestic tourism consumption. Such as interest rate, liquidity constraints, income gap, the relationship between uncertainty factors and the domestic tourism consumption. The macroeconomic factors and the relation of the tourism study will be issued in favor of the macro policy of the development of domestic tourism and provide a theoretical basis, which in many countries in tourism related literature is rarely mentioned.

In summary, on the domestic tourism consumption as the focus of development of the tourism consumption with the needs of the present economic situation of our country, is also in line with the masses of urban and rural residents, improve the quality of life, broaden their horizons and increase the interests of the happiness index. To study the effects of domestic tourism consumption demand factors and consumption mechanism, help to suit the remedy to the case and promote the health of the domestic tourism sustainable development "although scholars has on the domestic tourism market have done many studies, but in terms of theoretical research and empirical research point of view, there are still many questions need answering. Therefore, research on domestic tourism consumption theory has a strong theoretical and practical significance. 


\section{Literature Review}

\subsection{Domestic Tourism}

The definition of domestic tourism is quite simple: said in his own country of tourists travel for domestic tourism, domestic tourism, and to travel in other countries known as an international tourism, the concept of the tourist from World Tourism Authority WTA temporary home or a short trip for more than 24 hours[3]. From this concept can be sum up two points: first, the tourists must in destinations overnight; second, the distinction between domestic and international tourism is to the national territory as the standard to classify. When consumers buy goods for tourism products, it is called tourism demand, namely: there is a desire to travel consumers in a particular period, at a price level is willing to be able to buy the number of tourist products [4-5]. Obviously, tourism demand can be divided into domestic tourism demand and international tourism demand. It is worth to pay attention to, the tourism activity has its particularity - one is that the use value of tourism is to achieve the flow of people and the flow of none. General consumer activities in obtaining the right to use the goods, consumers have access to the ownership of goods; consumers can take home to enjoy the goods, which produced a transfer of ownership. However tourists after obtaining the right to the use of a tourism commodity, but cannot transfer ownership, only to the movement of people instead of moving objects to enjoy the product "as a result, leisure time is realization of tourism activities and a necessary condition. That is to say willingness to travel and purchasing power and no leisure time, travel demand is also unable to meet, the amount of leisure time concentrated scattered degree will directly affect the size of the economic and tourism consumption.

According to the three conditions of the tourism demand, the scholars also divided the tourism demand into the desire of the potential tourism demand and the reality of tourism demand. Refers to the willingness of the potential tourism demand, tourism will, but due to time and buy the lack of capacity and the inability to achieve demand; tourism demand of the reality show is three conditions are met the demand, but this demand may also affected by unmeasured factors and couldn't make the trip unwanted potential tourism demand, tourism consumption is not intended as a wish mandatory alternative tourism demand, and in line with the intention of tourism demand, the two kinds of demand is to realize the tourism demand, tourism consumption. Domestic tourism consumption is a component of the tourism consumption, the concept of tourism consumption is clearly helpful to the concept of domestic tourism consumption. Academic existence of the two concepts of tourism consumption and tourism consumption of the controversy, the tourist consumption is included in the whole process of food, travel, travel, travel, shopping, entertainment and other consumer. Tourist consumption includes more extensive content, in addition to the travel of the consumer, but also included in the travel, tourism consumption[6]. For example, before the purchase of consumer cameras, photo processing line, visible tourism consumption is the general concept of tourist consumption. This article believes that the tourism consumption statistics already exist many difficulties, such as consumption in tourism destination restaurant, how much should be included in the tourist consumption, and how much should be included in the daily consumption of local residents. On the local traffic, shopping also exist the same situation, if coupled with the anterior and the consumption, in statistics will produce even greater difficulties. Tourism consumption using the concept of tourist consumption at least technically, theoretically clear research objects [7]. Therefore, the tourism consumption refers to the consumption of tourists, using the WTO definition of tourism consumption; tourism consumption refers to the development of tourism activities! Caused by consumption, tourism for their use or produce the value of goods and services, a clear definition of the meaning of two layers: first, the economic significance of tourism consumption, tourism consumption is the sum of the value of tourism commodities and 
services; second, the statistics of tourism consumption from the perspective of tourists use statistics, also from the supplier's perspective, the consumption of the same can be said to be consumers consumed, but also can be said to be the supplier sold, both of which led to the generation of tourism consumption.

\subsection{Tourism Consumption Demand}

There are many ways to study tourism demand, classification scholars are not the same, Archer has seventy years of the last century sixty's tourism demand did review, he thought the research methods of tourism demand mainly has two kinds of quantitative and qualitative prediction form, the first is to analysis and formation the data of mathematical economics or statistics model, including multivariate regression analysis and gravity and travel mode; the second is for each group of experts to forecast demand future[8]. The earliest econometric method out of the causal relationship in the study of the tourism consumption demand, usually by regression analysis method to estimate the quantitative relation between tourism demand and the variables, through historical data from before the variable coefficient estimation, forecast data and finally draws the tourism demand, measure economic model has a solid theoretical background. Its theoretical basis is the economic law of demand and tourism in the dumbbell economic model. In economics, the law of demand is the same in other conditions, people's demand for a commodity with the commodity price changes in the opposite direction of change, as commodity prices rising demand. With the decline in commodity prices, also increased demand, law of tourism demand is the same in other conditions, people demand for a tourist destination with the tourism destination price changes in reverse direction, i.e. demand decreases with the rise of tourism demand or price, with the decline of tourism price increases.

First of all, tourism consumption and tourism demand in the academic research and statistical calculation often replace each other, tourism consumption is an economic concept, refers to the tourism destination from the tourism related industries on the economic income, and the income is to be realized for tourism demand. Although the potential tourism demand that tourism demand is greater than the tourism consumption, but the potential tourism demand is difficult to measure and in the strict sense is not the potential demand for tourism demand. Because it does not meet the definition of demand, but the lack of effective demands, and plays an important role in the research on the effective transformation of potential tourism demand. Secondly, tourism consumption reflects the degree of health. Tourism supply and demand related tourism consumption is consumers create economic value, has been the number of meet travel demand. Through the consumption and Supply of contrast, you can test whether there is excess supply, whether there is no demand for products and services exist, tourism consumption can also test whether there are tourists not satisfied with the demand for tourism.

\section{Tourism Consumption Theory and Model}

Tourism economics is a branch of Applied Economics, the study of domestic tourism consumption should be established in the economics of consumer research based on, and combining the characteristics peculiar to the tourism consumption in order to get in line with the economic law of tourism consumption, domestic tourism consumption reflects is the domestic tourists of tourism products in the domestic purchasing power. Tourism demand function based on the relationship between price and quantity demanded and their economic significance as in the other conditions remain unchanged, lower commodity prices, demand is higher and higher. On the basis of the relationship between price and demand, and then add other impact factors will be extended to practice the use of tourism demand function. The original tourism demand function includes tourism price, disposable income, tourists' interests and hobbies. Leiper (1990) presents the basic tourism 
system; the model constructed the basic structure of tourism demand: occurred in the tourist market demand is the main phenomenon, occurring in the phenomenon of main body of tourism destination supply, competition relationship between tourism destination and between tourist destination and tourist policy and regulation. Tourist demand has three components: the tourist destination, the destination and the tourist channel. Tourism demand eventually focused on the destination, that is, from the source of tourists through the tourist channel, and ultimately to the destination to the number of tourist consumption. Based on this, the travel demand must first research group of consumers, and economic conditions, the ability to understand consumers' economy, consumer preferences, consumption desire, leisure time, tax policy and tourism spending limits. Second, to analyze the supply situation of tourism destination, the destination of the analysis includes the analysis of destination attractiveness, the purpose of the supplier's analysis, and the analysis of the competitive relationship between destination and other destinations. Analysis, appeal and need to on its structure and hierarchical solutions constitute basic appeal, auxiliary attractive and sustainable attraction of supplies manufacturers, to the destination tourism related supplier of behavior, including price behavior, behavior of promotion and integration analysis; competition between research and other destinations to destination in the competition of price behavior, promotion behavior. Third, analysis of the tourism channel, tourism supply and demand in addition to the selection of joint by tourists, tourism channel whether there is close relationship between the patency and the government and the government under the leadership of the system innovation and regulation, to some extent, and even can be said that the government system determines the travel channel unobstructed; and the main interest of the government itself is the tourism economy in particular, a series of acts of this special interest groups will have an important impact on the tourism supply manufacturers, including the market structure, the influence of firm behavior and market performance and other aspects, so the research on tourism demand, to promote the innovation of the system of government through the tourism economy through the analysis of strategic development.

$$
D=f(O, D, C)
$$

In this formula, $\mathrm{D}$ represents the demand for tourism destination; $\mathrm{O}$ represents for tourists to the economic factors, D represents economic factors of destination, $\mathrm{C}$ represents economic factors between the two places. Dumbbell model establishment, originally scattered factors such as price, income and so on to belong to the system, changing the initial Tourism demand function factor is introduced into the random problems.

Source factors actually include two parts: one is the source of the consumers personal factors: personal discretionary income level, consumption habits, the right to resort; the second is the source of macroeconomic factors: the distribution of income, interest rates, tax system and tourism spending limits.

1) Personal disposable income level:Disposable personal income level when the precondition of tourism demand of the decision, Keynes consumption function, personal disposable income increase lead to the increase of tourism consumption, tourism is not the necessities of life, the tourism consumption is to meet people's enjoyment of the demand, so tourism consumption is a people in leisure state to a higher level of consumption activities.

2) Income distribution: consumption function based on a priori assumptions, the marginal propensity to consume is decreasing, the higher the income, the smaller the marginal propensity to consume, the smaller the proportion of consumption in the income. Rational consumers will not only according to 
the current income, but also to choose a life according to the information of expected future income and consumption, in obedience to a relatively stable optimal consumption path.

3) Consumption habits: understanding the consumption habits in the scholars exist different views "some believe that tourism has become a consumption habits, somewhere residents are more likely to spend their money to travel to, the archer summary of travel demand function tourist interest, hobby factor is consistent, which is consistent with the elements of the three elements of Tourism demand of tourism motivation.

4) Right to resort: Vacation right means the number of leisure time, leisure time as a necessary condition for tourism demand, and its increase will cause the increase of tourism demand. It is generally believed that the system of paid leave is an indispensable supporting policy after the rise of mass tourism in 1960s. It can be said that there is no public tourism without paid leave system.

Objective factors are mainly in the following aspects:

1) The overall price level: The most direct influence factor of tourism products is the price of tourism demand, the price of goods or services and other related goods or services prices, is the most important determinant of consumer potential tourists may decide to choose to spend small tourism projects in order to have more money to spend on other projects, this tendency in the goods and services of substitutes and complements behave is very obvious.

2) Supply competition level: Supply competition determines the economic efficiency of the objective to vendors and destination supplies manufacturers competition degree is high, the allocation of resources more reasonable, more fully use the resources, tourism commodity prices lower, tourism consumers satisfaction is bigger.

3) The quality of tourism products: Tourism product quality the most direct expression as a tourist attraction the occurrence condition, it is affiliated facilities of tourism development, dependence of core resources. The basic elements include such as museums, theatre and other venues, and various natural and cultural landscapes; secondary elements including hotels, catering, shopping; additional elements include accessibility, internal traffic, parking facilities and tourist information provided and so on.

\section{Empirical Analysis}

\subsection{Samples and Variables}

This study to examine is domestic tourism consumption in the form elements and how to improve the residents' domestic tourism consumption, research object positioning in urban and rural residents, sample is required only with domestic tourism related data. The dependent variable (C) for the domestic tourism consumption, which meets the requirement of linear regression in continuous variables and follow normal distribution, so the empirical model fitting using multiple linear regression model. In this paper, the definition of tourism consumption is part of GDP, the total number of penetration rates and have no direct relationship with GDP reflect the average per capita spending, spending is in the domestic tourism population, and not to the entire population as the base, and other per capita indicators are not comparable, so the total number of travel rate and per capita rate does not meet the requirements. Total tourism spending is directly part 
of GDP, you can convert all adult consumption to get between with other indicators of comparability, the most in line with the demand. At the same time, the domestic tourism consumption has obvious characteristics of the two structure in urban and rural areas, so this paper were collected from urban residents and rural residents Domestic tourism consumption data model as the dependent variable. This study uses is the domestic tourism consumption in the official statistics, in order to ensure the timeliness of selected data for 2005-2015 time series data "in this paper, all the calculation and result output are by the statistical software SPSS to complete the implementation of and use the software provides the descriptive analysis, correlation analysis and multiple linear regression analysis method.

\subsection{Data Analysis and Hypothesis Testing}

This study used $\mathrm{R}^{2}$ in a multiple regression model fitting effect contains all the variables of the model analysis of "decision coefficient table from the urban residents' consumption model, can be seen in Table $1 . \mathrm{R}^{2}$ is $96.8 \%$, the adjusted $\mathrm{R}^{2}$ was $95.3 \%$, namely the model variables can explain the change of strain $95.3 \%$, and table analysis from the variance of urban residents' consumption model, can be seen in Table 2; the model through the $\mathrm{F}$ test, which shows that the model fitting is satisfactory from the consumption of rural residents. The model decision coefficient can be seen in Table $3, \mathrm{R}^{2}$ is $98.7 \%$, the adjusted $\mathrm{R}^{2}$ was $98.6 \%$, that of the model independent variables can explain $98.6 \%$ of the variation of strain, and then analysis of variance model from the consumption of rural residents can be seen in Table 4 , the model through the F test shows that the fitting degree of the model is satisfactory.

Table 1.Consumption Model Decision Coefficient of Urban Residents

\begin{tabular}{|c|c|c|c|c|c|}
\hline Model & $\mathrm{R}$ & R Square & $\begin{array}{c}\text { Adjusted R } \\
\text { Square }\end{array}$ & $\begin{array}{c}\text { Std. Error of } \\
\text { the Estimate }\end{array}$ & $\begin{array}{c}\text { Durbin- } \\
\text { Watson }\end{array}$ \\
\hline 1 & $.984(\mathrm{a})$ & .968 & .953 & 4.731346 & 1.144 \\
\hline
\end{tabular}

Table 2. Variance of Consumption Model of Urban Residents

\begin{tabular}{|c|c|c|c|c|c|}
\hline Model 1 & $\begin{array}{c}\text { Sum of } \\
\text { Squares }\end{array}$ & df & $\begin{array}{c}\text { Mean } \\
\text { Square }\end{array}$ & F & Sig. \\
\hline Regression & 6849.149 & 5 & 1369.83 & 61.19 & $.000(\mathrm{a})$ \\
\hline Residual & 223.85 & 10 & 22.38 & & \\
\hline Total & 7073.006 & 15 & & & \\
\hline
\end{tabular}

Table 3. Consumption Model Decision Coefficient of Rural Residents

\begin{tabular}{|c|c|c|c|c|c|}
\hline Model & $\mathrm{R}$ & R Square & $\begin{array}{c}\text { Adjusted R } \\
\text { Square }\end{array}$ & $\begin{array}{c}\text { Std. Error of } \\
\text { the Estimate }\end{array}$ & $\begin{array}{c}\text { Durbin- } \\
\text { Watson }\end{array}$ \\
\hline 1 & $.994(\mathrm{a})$ & .987 & .986 & 2.186534 & 1.919 \\
\hline
\end{tabular}

Table 4. Variance of Consumption Model of Rural Residents

\begin{tabular}{|c|c|c|c|c|c|}
\hline Model 1 & $\begin{array}{c}\text { Sum of } \\
\text { Squares }\end{array}$ & df & $\begin{array}{c}\text { Mean } \\
\text { Square }\end{array}$ & F & Sig. \\
\hline Regression & 4894.27 & 2 & 2447.13 & 511.853 & $.000(\mathrm{a})$ \\
\hline Residual & 62.15 & 13 & 4.78 & & \\
\hline Total & 4956.42 & 15 & & & \\
\hline
\end{tabular}




\subsection{Descriptive Statistics}

The main variables of urban residents' consumption model of the descriptive statistics (Table 5), as can be seen from the table, some indicators of the standard deviation is relatively large, the data scattered. The first one is the per capita disposable income, the maximum and minimum values were 1934.63 and 1010.35 , the average is 1611.59 , and the standard deviation is second 216.40 . is the per capita consumption, the minimum value is 79.48 , the maximum value is 7.50 , the average is 121.33 , the standard deviation is 21.71 "second kinds of index standard deviation is relatively small, the data show that these indicators are relatively concentrated. Promotional efforts, the minimum is 0.0600 , the maximum is 1.0700 , the average is 0.40875 , the standard deviation is 0.3443 ; the liquidity constraint, the minimum value is 0.1626 , the maximum value is 0.2374 , the average is 0.2007 , the standard deviation is 0.028 ; the income gap, the minimum is 0.2991 , the maximum is 0.4604 , the average is 0.3779 , the standard deviation of 0.06911 .

Table 5. Descriptive Statistics on the Consumption of Urban Residents

\begin{tabular}{|c|c|c|c|c|c|}
\hline Factor & $\mathrm{N}$ & Minimum & Maximum & Mean & Std.Deviation \\
\hline $\begin{array}{c}\text { Per capita } \\
\text { consumption }\end{array}$ & 16 & 79.4813 & 157.496 & 121.33331 & 21.714827 \\
\hline $\begin{array}{c}\text { per capita income } \\
\text { leisure time }\end{array}$ & 16 & 1010.348 & 1934.632 & 1611.59283 & 216.40307 \\
\hline $\begin{array}{c}\text { Consumption } \\
\text { consciousness }\end{array}$ & 16 & 1.92 & 6.70 & 4.0381 & 1.77158 \\
\hline product price & 16 & 132.511 & 187.2035 & 160.9456 & 15.57131 \\
\hline Supply quality & 16 & 26.340 & 53.850 & 36.7737 & 9.24994 \\
\hline interest rate & 16 & .36 & 3.15 & 1.513 & 1.03518 \\
\hline Support strength & 16 & 1 & 2 & 1.50 & .516 \\
\hline Promotion efforts & 16 & .06000 & 1.0700 & .40875 & .344303 \\
\hline income disparity & 16 & .2991 & .4604 & .37793 & .06911 \\
\hline $\begin{array}{c}\text { Liquidity } \\
\text { constraints }\end{array}$ & 16 & .1626 & .2374 & .20073 & .02825 \\
\hline Uncertainty & 16 & 26.925 & 36.084 & 30.4618 & 2.22251 \\
\hline Valid N(list wise) & 16 & & & & \\
\hline
\end{tabular}

The main variable consumption model of rural residents of the descriptive statistics (Table 6), as can be seen from the table, some indicators of the standard deviation is relatively large, the data scattered. Poor 0.07760 .021440 .3516 , respectively for 0.3786 0.32100 .0041 ; for the poor and the first one is the per capita disposable income, the maximum and minimum values, respectively 600,18 265.67 mean 468.26 standard was 80.41 second per capita consumption, minimum 6.84 , the maximum value of 67.26 , mean 3.197, standard deviation was 18.18; the second class index standard deviation is relatively small, show that the data are relatively more concentrated "these indicators are promotional efforts, the minimum is 0.0006 , the biggest 0.0107 , mean and standard deviation 0.0034; income gap, the minimum value for the maximum value, the mean, standard deviation, deterministic index minimum is 0.0000 , the maximum for the mean 0.1385 standard 0.02980 . 
Table 6. Descriptive Statistics on the Consumption of Rural Residents

\begin{tabular}{|c|c|c|c|c|c|}
\hline Factor & $\mathrm{N}$ & Minimum & Maximum & Mean & Std.Deviation \\
\hline $\begin{array}{c}\text { Per capita } \\
\text { consumption }\end{array}$ & 16 & 6.8362 & 67.258 & 31.97184 & 18.1776876 \\
\hline per capita income & 16 & 265.667 & 600.176 & 468.2555 & 80.4111832 \\
\hline leisure time & 16 & 0 & 1 & .63 & .500 \\
\hline $\begin{array}{c}\text { Consumption } \\
\text { consciousness }\end{array}$ & 16 & .20 & 1.70 & .6563 & .47183 \\
\hline product price & 16 & 20.7170 & 70.222 & 44.36842 & 15.10081 \\
\hline Supply quality & 16 & .2634 & .5385 & .36773 & .0924994 \\
\hline interest rate & 16 & .36 & 3.15 & 1.513 & 1.03518 \\
\hline Support strength & 16 & 1 & 2 & 1.50 & .516 \\
\hline Promotion efforts & 16 & .0006 & .0107 & .00408 & .0034430 \\
\hline income disparity & 16 & .3210 & .4784 & .35157 & .0214417 \\
\hline $\begin{array}{c}\text { Liquidity } \\
\text { constraints }\end{array}$ & 16 & .0255 & .2962 & .168944 & .108056 \\
\hline Uncertainty & 16 & .0000 & .0776 & .013850 & .0298018 \\
\hline Valid N(list wise) & 16 & & & & \\
\hline
\end{tabular}

\subsection{Correlation Relationship}

We analyze the relationship between urban residents' domestic tourism consumption and the individual elements level, as shown in the Table7.

Table 7.Relationship between Tourism Consumption of Urban Residents

\begin{tabular}{|c|c|c|c|c|c|}
\hline & ble & $\begin{array}{l}\text { Per capita } \\
\text { consumption }\end{array}$ & $\begin{array}{c}\text { per } \\
\text { capita }\end{array}$ & $\begin{array}{l}\text { leisure } \\
\text { time }\end{array}$ & Consumption \\
\hline Per capita & $\begin{array}{c}\text { Pearson } \\
\text { Correlation }\end{array}$ & 1 & $.871(* *)$ & $.655(* *)$ & $.761(* *)$ \\
\hline consumption & Sig.(2-tailed) & .00 & .00 & .006 & .001 \\
\hline & $\mathrm{N}$ & 16 & 16 & 16 & 16 \\
\hline per capita & $\begin{array}{c}\text { Pearson } \\
\text { Correlation }\end{array}$ & $.871(* *)$ & 1 & $.627(* *)$ & $.733(* *)$ \\
\hline income & Sig.(2-tailed) & .000 & .00 & .009 & .001 \\
\hline & $\mathrm{N}$ & 16 & 16 & 16 & 16 \\
\hline & $\begin{array}{c}\text { Pearson } \\
\text { Correlation }\end{array}$ & $.655(* *)$ & $.627(* *)$ & 1 & $.781(* *)$ \\
\hline leisure time & Sig.(2-tailed) & .006 & .009 & .00 & .00 \\
\hline & $\mathrm{N}$ & 16 & 16 & 16 & 16 \\
\hline Consumption & $\begin{array}{c}\text { Pearson } \\
\text { Correlation }\end{array}$ & $.761(* *)$ & $.733(* *)$ & $.781(* *)$ & 1 \\
\hline consciousness & Sig.(2-tailed) & .001 & .001 & .000 & . \\
\hline & $\mathrm{N}$ & 16 & 16 & 16 & 16 \\
\hline
\end{tabular}

From the table we can see that domestic tourism consumption and per capita income at the 0.01 level significant correlation, the correlation coefficient of 0.871 that China's urban residents per capita disposable income is higher, more domestic tourism consumption, domestic tourism consumption and leisure time at 0.01 significant level significantly, correlation coefficient to 0.655 , shows that China's urban residents personal 
more leisure time, the greater the domestic tourism consumption. Domestic tourism consumption and consumer awareness are significantly related to the level of 0.01 , the correlation coefficient is 0.761 , which shows that the higher education level of urban residents in China, the stronger the domestic tourism consumption ability.

Also, we analyze the relationship between rural residents' domestic tourism consumption and individual factors as shown in Table 8. It can be seen from the table, the domestic tourism consumption and per capita income significantly correlated at 0.01 significant level, the correlation coefficient was 0.869 , indicating the per capita net income of rural residents is higher, the greater the domestic tourism consumption domestic tourism consumption and leisure time significantly correlated at 0.01 significant level, the correlation coefficient was 0.782 , indicating Chinese rural residents more leisure time, domestic tourism consumption is larger. Domestic tourism consumption and consumer awareness in the 0.01 significant level of significant correlation, the correlation coefficient was 0.933 , indicating the higher China in rural areas residents' education level, domestic tourism consumption ability is strong

Table 8. Relationship between Tourism Consumption of Urban Residents

\begin{tabular}{|c|c|c|c|c|c|}
\hline \multicolumn{2}{|c}{ variable } & $\begin{array}{c}\text { Per capita } \\
\text { consumption }\end{array}$ & $\begin{array}{c}\text { per capita } \\
\text { income }\end{array}$ & $\begin{array}{c}\text { leisure } \\
\text { time }\end{array}$ & $\begin{array}{c}\text { Consumption } \\
\text { consciousness }\end{array}$ \\
\hline \multirow{3}{*}{$\begin{array}{c}\text { Per capita } \\
\text { consumption }\end{array}$} & $\begin{array}{c}\text { Pearson } \\
\text { Correlation }\end{array}$ & 1 & $.869(* *)$ & $.782(* *)$ & $.933(* *)$ \\
\cline { 2 - 6 } & Sig.(2-tailed) & .00 & .00 & .006 & .00 \\
\cline { 2 - 6 } & $\mathrm{N}$ & 16 & 16 & 16 & 16 \\
\hline \multirow{3}{*}{$\begin{array}{c}\text { per capita } \\
\text { income }\end{array}$} & $\begin{array}{c}\text { Pearson } \\
\text { Correlation }\end{array}$ & $.869(* *)$ & 1 & $.638(* *)$ & $.802(* *)$ \\
\cline { 2 - 6 } & Sig.(2-tailed) & .000 & .00 & .009 & .001 \\
\cline { 2 - 6 } & $\mathrm{N}$ & 16 & 16 & 16 & 16 \\
\hline \multirow{4}{*}{$\begin{array}{c}\text { leisure time } \\
\text { Consumption }\end{array}$} & $\begin{array}{c}\text { Pearson } \\
\text { Correlation }\end{array}$ & $.782(* *)$ & $.638(* *)$ & 1 & $.661(* *)$ \\
\cline { 2 - 6 } consciousness & Sig.(2-tailed) & .00 & .008 & .00 & .005 \\
\cline { 2 - 6 } & Correlation & $.933(* *)$ & $.802(* *)$ & $.661(* *)$ & 16 \\
\cline { 2 - 6 } & Sig.(2-tailed) & .00 & .00 & .005 & .00 \\
\cline { 2 - 6 } & $\mathrm{N}$ & 16 & 16 & 16 & 16 \\
\hline
\end{tabular}

\section{Conclusions}

The empirical results show that urban residents' elements of domestic tourism consumption in the individual income level, leisure time, consumer awareness has effect on domestic tourism consumption, has a significantly positive correlation between the degree of competition and the quality of supplier supply. Elements of the influence of the domestic tourism consumption of urban residents, has a significant positive correlation. And the key influence of rural resident's consumer factor is the price of tourism products and tourism intention. From the domestic tourism consumption of rural residents pulling strength, stimulate consumer awareness on rural residents' domestic tourism consumption is the biggest, the rate of higher education among rural residents every $1 \%$ increase can increase 32.16 RMB to increase the price of tourism products is also to the countryside residents per capita domestic tourism consumption contribute to rural residents per capita domestic tourism consumption, the price increase for each $1 \mathrm{RMB}$, urban residents The per capita domestic tourism consumption will increase 0.429 RMB. China's economic development has also brought the domestic residents increasing education and upgrading 
of consumption concept, national consumption concept to achieve a rapid development in a short period of 20 years, the tourism consumption concept update, domestic tourism the non-necessities of life has gradually entered into the people's life, become our people broaden their horizons, improve self-cultivation, relax the tool, average consumption tendency of tourism consumption (APC) is greater than the average propensity to consume daily consumption of residents is the best proof of people's change, urban and rural residents will be more willing to spend tourism products instead of other consumer products is not only the improvement of income also, the results of the updated concept of consumption.

Although the consumption concept of urban and rural residents in China is constantly updated, we must also see that our country still has a large number of rural residents still stick to the old concept of consumption, thus hindering the development of rural domestic tourism consumption. For rural residents, to raise consumer awareness of domestic tourism can greatly improve the domestic tourism consumption, although the improvement of income of domestic tourism consumption growth has a role in promoting is not the most important factor, indicating that restrict the rural residents to participate in the factors of domestic tourism is their willingness, even if economic conditions is not limited, domestic tourism is not they want to buy products, with its culture and education level. Due to the cultural level is not high, some rural residents lack of external different culture of curiosity and desire to explore "this prompted us should adopt relevant policies and raise the educational level of rural residents, especially the need to increase the rate of the rural residents and the higher education, so as to promote domestic tourism consumption of rural residents.

\section{References}

[1] K. Elisabeth and J. Maria, "Understanding and managing the rural tourism experience-The case of a historical village in Portugal”,Tourism Management Perspectives, vol.4, (2012), pp.207-214.

[2] F. A. Samuel and K. Catheryn, "A Framework for Rural Tourism Destination Management and Marketing Organisations,Procedia-Social and Behavioral Sciences, vol.144, (2014), pp.151-163.

[3] P.Gyan and P.Surya, "Application of appreciative inquiry in tourism research in rural communities", Tourism Management, vol.33, (2012), pp.978-982

[4] L.Littoral and P.Anderson, "What Makes craft Souvenir Authentic",Annals of Tourism Research, vol.20, (1993), pp. 197-215.

[5] A.Elspeth and N.Robin, "The relationship between personality gender and tourist behavior",Tourism Management, vol.20, (1990), pp. 193-202.

[6] B.François and L.Anne, "Domestic demand for tourism in rural areas: Insights from summer stays in three French regions, Tourism Management”, vol.46, (2015), pp. 562-570.

[7] G. Mansour and M.Omid, "An application of European Performance Satisfaction Index towards rural tourism: The case of western Iran", Tourism Management Perspectives, vol.11, (2014), pp.77-82.

[8] K.Raija, "The role of individual entrepreneurs in the development of competitiveness for a rural tourism destination-A case study", Tourism Management, vol.40, (2014), pp.361-371.

\section{Authors}

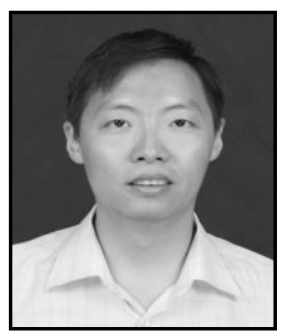

Tan Qihong, (1979.6), Xi'an, Shaanxi, P.R.China Current Position, grades: the lecturer of School of Leisure Management, Xi' an Eurasia University, Shaanxi, China. Scientific interest: His research interest fields include tourism \& culture industry; tourism market. Publications: more than 10 papers published Experience: 13 years teaching experience and completed 7 scientific research projects. 
International Journal of Smart Home

Vol. 10, No. 5 (2016) 